\title{
Condylomata acuminata in children: report of four
} \section{cases}

\author{
MOHAMMED AMEEN SAIT AND B R GARG \\ From the Department of Dermatology and Sexually Transmitted Disease, Jawaharlal Institute of \\ Postgraduate Medical Education and Research, Pondicherry, India
}

SUMMARY Four cases of condylomata acuminata in children (two boys, two girls) are reported. Three children had perianal warts and one vulvar warts. One of the four children had been sexually assaulted, but a history of sexual contact was absent in the other three. Surgical excision was undertaken in one case and the others responded well to the local application of $25 \%$ podophyllin in benzoin tincture compound. In the absence of sexual contact, a non-coital mode of transmission of infection could be a possibility.

\section{Introduction}

Condylomata acuminata are epithelial tumours caused by a human papillomavirus (HPV) of the papova group, ${ }^{1}$ which affects the genitalia, perianal region, rectal and urethral mucosae, and sometimes the oral cavity. ${ }^{2}$ Although several types of HPV have been isolated, HPV type 6 has been found to be predominantly associated with these warts. ${ }^{3}$ Both sexes are affected equally, and the infection is usually transmitted by sexual intercourse, ${ }^{4}$ although spread by autoinoculation from the hands may sometimes occur. ${ }^{5}$ The peak incidence occurs in people in their $20 \mathrm{~s},{ }^{4}$ and reports of condylomata acuminata in children are rare.

\section{Case reports}

The table summarises the cases described in this report.
CASE 1

A $1 \frac{1 / 2}{2}$ year old boy was brought to the outpatient department of this institute by his parents, who had noted a growth in the perianal region for four months. The child had been born by vaginal delivery after full term normal pregnancy. There was no history of either genital or skin warts in the parents or in other members of the family. Examination showed a large dry warty growth around the perianal margin, which obscured the anal orifice (fig 1). The external genitalia and rectal mucosa were normal, and no other abnormality was seen. Examination of the parents showed no verrucae. Serological tests for syphilis in the child and his parents gave negative results. Histological examination of the tissue showed the typical features of condylomata acuminata, which consisted of parakeratosis, irregular pronounced acanthosis giving a picture of pseudoepitheliomatous hyperplasia, and (the most characteristic and diagnostic findings) vacuolated

TABLE Summary of four cases described

\begin{tabular}{|c|c|c|c|c|c|c|c|}
\hline \multirow{2}{*}{$\begin{array}{l}\text { Case } \\
\text { No }\end{array}$} & \multirow[b]{2}{*}{ Age } & \multirow[b]{2}{*}{ Sex } & \multirow{2}{*}{$\begin{array}{l}\text { Duration } \\
\text { of lesions }\end{array}$} & \multirow{2}{*}{$\begin{array}{l}\text { Sites } \\
\text { affected }\end{array}$} & \multicolumn{2}{|c|}{ Investigations } & \multirow[b]{2}{*}{ Treatment } \\
\hline & & & & & $V D R L$ & Biopsy & \\
\hline $\begin{array}{l}1 \\
2 \\
3 \\
4\end{array}$ & $\begin{array}{l}11 / 2 \text { years } \\
8 \text { months } \\
11 / 2 \text { years } \\
12 \text { years }\end{array}$ & $\begin{array}{l}\mathbf{M} \\
\mathbf{M} \\
\mathbf{F} \\
\mathbf{F}\end{array}$ & $\begin{array}{l}4 \text { months } \\
2 \text { months } \\
2 \text { months } \\
15 \text { days }\end{array}$ & $\begin{array}{l}\text { Perianal } \\
\text { Perianal } \\
\text { Perianal } \\
\text { Vulval }\end{array}$ & $\begin{array}{l}\text { Negative } \\
\text { Negative } \\
\text { Negative } \\
\text { Negative }\end{array}$ & $\begin{array}{l}\mathbf{C A} \\
\mathbf{C A}\end{array}$ & $\begin{array}{l}\text { Excision } \\
\text { Podophyllin } \\
\text { Podophyllin } \\
\text { Podophyllin }\end{array}$ \\
\hline
\end{tabular}

VDRL = Venereal Disease Research Laboratory test for syphilis.

$\mathrm{CA}=$ Condylomata acuminata (biopsy not performed in cases 3 and 4). 

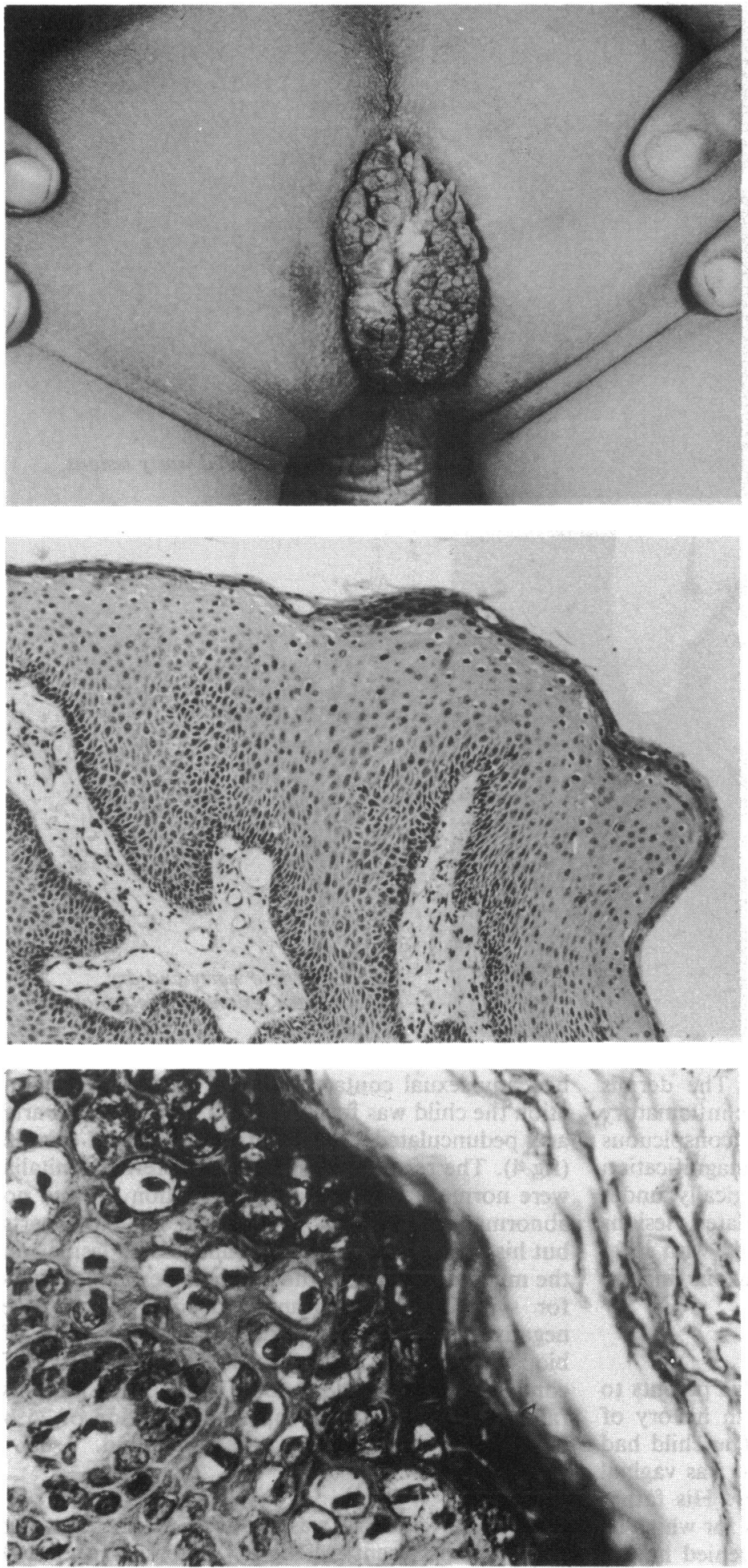

FIG 1 Large cauliflower like growth of condylomata acuminato in perianal region obscuring anal orifice.

FIG 2 Parakeratosis, irregular acanthosis, and diagnostic vacuolated cells in the upper stratum malphigii ( $\times 100$ original magnification).

FIG 3 Diagnostic virus infected vacuolated cells of stratum malphigii as seen under high power magnification ( $\times 400$ original magnification). 

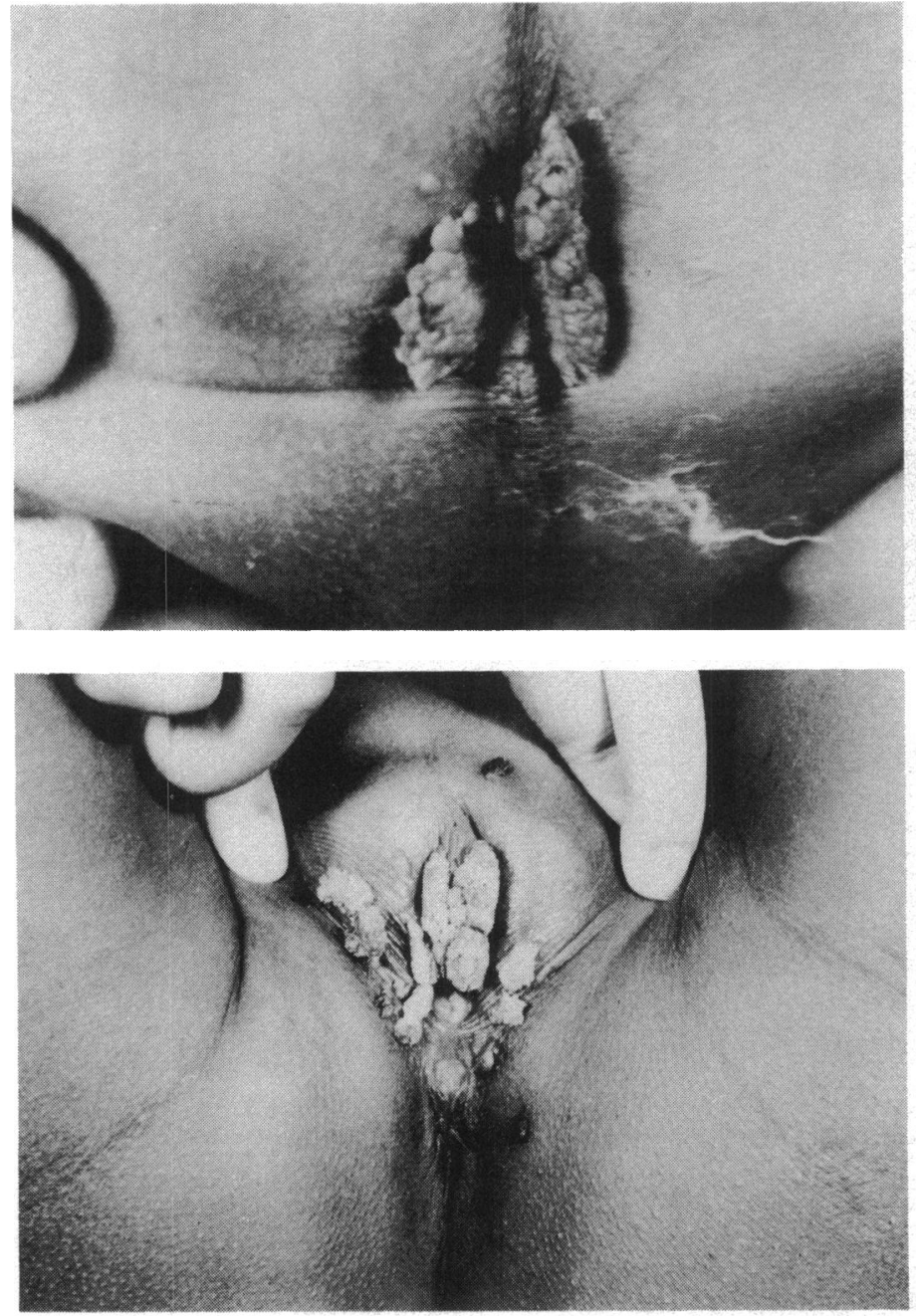

cells in the upper stratum malphigii. The dermis showed dilated capillaries and a chronic inflamatory infiltrate (fig 2). Figure 3 shows the conspicuous vacuolated cells seen under high power magnification ( $\times$ 400). The lesion was excised surgically under general anesthesia. A few pedunculated lesions recurred, and were subsequently treated with local application of $25 \%$ podophyllin in benzoin tincture compound.

\section{CASE 2}

An 8 month old boy was brought by his parents to the skin department with a two month history of warty lesions in the perianal region. The child had been apparently normal at birth, which was vaginal delivery after an uneventful pregnancy. His father gave a $2 \frac{1}{2}$ year history of genital warts for which he had not received any treatment. He denied having
FIG 4 Pedunculated warty lesions in perianal region.

FIG 5 Multiple warty and dry pedunculated lesions of the female genitalia.

had any sexual contact with the child. On examination the child was found to have multiple dry warty and pedunculated growths around the anal margin (fig 4). The rectal mucosa and the external genitalia were normal, and systemic examination showed no abnormal features. His mother did not have warts but his father had small dry pedunculated lesions on the mucosal surface of the prepuce. Serological tests for syphilis in the infant and his parents gave negative results. Histopathological examination of biopsy specimens confirmed the diagnosis of condylomata acuminata. Both the infant and his father were treated with topical application of $25 \%$ podophyllin in benzoin tincture compound.

\section{CASE 3}

A $1 \frac{1}{2}$ year old girl was referred to the skin out patient department when her parents had noted 
growths in the perianal region for two months. The child had been born at full term by vaginal delivery. There was no history of either genital or skin warts in the parents or other siblings in the family. Examination of the child showed multiple, pedunculated warty lesions around the anal margin. The parents did not have genital or skin warts. Serological tests for syphilis in the child and the parents gave negative results. The patient defaulted from treatment after the first application of podophyllin.

\section{CASE 4}

A 12 year old girl who had not yet attained menarche was brought to the skin out patient department by her older sister. She had had skin lesions over the external genitalia for 15 days. The girl had been sexually assaulted by an elderly man. On examination typical multiple pedunculated lesions of condylomata acuminata were present over both the labia majora, at the fourchette, and the clitoris (fig 5). A scanty whitish discharge was found trickling from the vagina. The hymen was intact, and no lesions were found elsewhere. Serological tests for syphilis gave negative results. We applied $25 \%$ podophyllin topically on alternate days, but the lesions responded only after multiple applications.

\section{Discussion}

Condylomata acuminata are considered to be rare in children. ${ }^{6-10}$ Stumpf, however, stated that the incidence of these lesions in children appeared to be rising. ${ }^{11} \mathrm{He}$ noted that 22 such cases had been documented in reports published in the English language from 1940 to 1980 including his own report of three cases. Zamora et al ${ }^{12}$ and Baruah et al ${ }^{13}$ have reported condylomata acuminata in a $2 \frac{1}{2}$ year old girl and a 1 year old boy respectively, and the present report adds another four cases to the list. The 8 month old boy included in the present report is the youngest case to be reported so far, and the $1 \frac{1}{2}$ year old girl is only the third instance of condylomata acuminata in a girl under 3 years old. The increasing incidence of genital warts in adults that has been observed in recent years probably provides a widespread source of infection and results in an increase in the incidence of similar lesions in children.

Perianal condylomata acuminata in adults are mainly acquired during anal intercourse. ${ }^{14}$ The exact mode of spread of infection in children, however, is poorly understood. Some cases have been reported in children after sexual assault or abuse, ${ }^{15}$ but in most cases there has been no such history, ${ }^{7} 711$-13 although in some instances the parents of the affected children were found to have genital warts or gave a history of such lesions. ${ }^{6} 121316$ In the report published here there was no history of sexual contact in three of the four cases, although in one case the child's father was found to have genital warts. The mode of acquisition of infection in the absence of sexual contact is uncertain. As in most instances of genital warts in children the informants are the parents, it is possible that due to social and medicolegal implications they deny a history of sexual contact with the children or they really have no knowledge of any sexual abuse of their children. Reports of genital warts in children by different workers, however, highlight the absence of sexual contact in the cases studied. Infection could be transmitted by non-coital means, such as autoinoculation, as stated by King and Nicol, ${ }^{5}$ or by accidental inoculation from parents to their children, as postulated by Baruah et al. ${ }^{13}$ Incidentally, Tang $e t$ al proposed transplacental hematogenous transmission, with selectivity of the genital warts virus for anal epithelium, in a premature boy presenting with perianal condylomata acuminata at birth. ${ }^{17}$

As malignant transformation of genital warts is known to occur, ${ }^{18} 19$ it is of the utmost importance that such lesions in children be treated promptly. Patel et $a l^{6}$ considered surgical excision to be the treatment of choice for large lesions of condylomata acuminata, as they respond poorly to topical applications. Topical preparations such as $25 \%$ podophyllin can be used with good results for sparse and localised lesions. In our experience several applications of podophyllin were required before any appreciable response could be obtained. Other treatments of genital warts in children have included topical sulfisoxazole, ${ }^{15} 5 \%$ ammoniated mercury ointment and fulgaration, ${ }^{7}$ cryotherapy, ${ }^{9}$ and immunotherapy with autovaccines. ${ }^{20}$

\section{References}

1. Oriel JD, Almeida JD. Demonstration of viral particles in human genital warts. British Journal of Venereal Diseases $1970 ; 46: 37-42$.

2. Ashiru JO, Ogunbanjo BO, Rotowa NA, Adeyemi-Doro FAB, Osoba AO. Intraoral condylomata acuminata: a case report. British Journal of Venereal Diseases 1983;59:325-6.

3. Jablonska S, Orth G. Recent advances in dermatology. 6th ed. London: Churchill Livingstone, 1983; 1-36.

4. Oriel JD. Natural history of genital warts. British Journal of Venereal Diseases 1971;47:1-13.

5. King AJ, Nicol C. Venereal diseases. 3rd ed. London: Baillière Tindall, 1975;326-7.

6. Patel $R$, Groff DB. Condylomata acuminata in childhood. Pediatrics 1972; 50: 152-3.

7. Grace DA, Ochsner JA, McLain CR, Smith JP. Vulvar condylomata acuminata in prepubertal females. JAMA 1967; 201: 137-8

8. Huffman JW. Disorders of the external genitals and vagina. Pediatr Clin North Am 1958;5:35-48.

9. Huffman JW. Vulvar disorders in premenarchal children. Clin Obstet Gynaecol 1960;3: 154-63.

10. Dewhurst CJ. Tumours of the genital tract in childhood and adolescence. Clin Obstet Gynaecol 1977; 20:595-6.

11. Stumpf PG. Increasing occurrence of condylomata acuminata in premenarchal children. Obstet Gynecol 1980;56:262-4.

12. Zamora S, Baumgartner G, Shaw M, Ordonez C, Guinan P. Condylomata acuminata in a $21 / 2$ year old girl. $J$ Urol 1983 ; 129: 145-6. 
13. Baruah MC, Lal S, Selvaraju M, Veliath AJ. Perianal condylomata acuminata in a male child. British Journal of Venereal Diseases 1984;60:60-1.

14. Oriel JD. Genital warts. Sex Transm Dis 1977;4:153-9.

15. Seidel J, Zanana J, Totten E. Condylomata acuminata as a sign of sexual abuse in children. J Pediatr 1979;95:553-5.

16. Goldman L, Feldman M, Levitt S. Condyloma acuminata in infants and children. Arch Dermatol 1976;112:1329.

17. Tang CK, Shermeta DW, Wood C. Congenital condylomata acuminata. Am J Obstet Gynecol 1978;131:912-4.
18. Lee SH, McGregor DH, Kuzier MN. Malignant transformation of perianal condyloma acuminatum. Dis Colon Rectum 1981; 24:462-7.

19. Ejeckam GC, Idikio HA, Nayak V, Gardiner JP. Malignant transformation in an anal condyloma acuminatum. Can J Surg 1983; 26: 170-3.

20. Abcarian $H$, Sharon $N$. Long-term effectiveness of the immunotherapy of anal condylomata acuminata. Dis Colon Rectum 1982;25:648-51. 